\title{
Colistin resistance among Gram-negative isolates in Nepal: A review
}

Devkota $\mathrm{SP}^{1 *}$, Paudel $\mathrm{A}^{2}$

*Corresponding author:

Mr. Surya Prasad Devkota, Lecturer, Department of Microbiology, Pokhara Bigyan Tatha Prabidhi campus, Nayabazzar, Pokhara, Nepal

${ }^{1}$ Lecturer, School of Health and Allied Sciences, Pokhara

University, Pokhara, Nepal

Email: devkotasp1@gmail.com ORCID

Information about the article:

Received: Jan. 15, 2020

Accepted: March 23, 2020

Published online: June 30, 2020

Cite this article:

Devkota SP, Paudel A. Colistin resistance among Gram-negative isolates in Nepal: A review. Journal of Biomedical Sciences. 2020;7(1):33-39

\section{Publisher}

Nepal Health Research Society, Bahundhara -6, Gokarnesowor Municipality, Kathmandu, Nepal

eISSN 2382-5545, ISSN 2676-1343 (Print)

(C) The Author(s). 2020

Content licensing: CC BY 4.0

\begin{abstract}
Background

Colistin resistance among Gram-negative isolates is a tremendous public health problem, and there are very few studies in Nepal about these pathogens. Hence, this review provides comprehensive data on colistin resistance among Gram-negative isolates from various samples in Nepal.
\end{abstract}

\section{Methods}

Articles reporting colistin resistance among various Gramnegative isolates from Nepal before July 2019 were selected; analyzed and relevant data was collected.

\section{Results}

Colistin resistance was low among clinical isolates (less than $6 \%$ ) in comparison to food and animal isolates (up to 69\%). A wide variety of clinical isolates were colistin-resistant in comparison to food and animal isolates. Many of these isolates were highly drug-resistant and also harbored various drug-resistant determinants.

\section{Conclusion}

Increased colistin resistance among Gram-negative pathogens is a serious concern. Screening of these isolates in clinical settings, animal farms, and food industries, as well as cautious use of colistin in both clinical and animal farms, is imminent.

\section{Keywords}

Clinical isolates, colistin resistance, Gram-negative isolates, multi-drug resistant, Nepal 


\section{Background}

Colistin, even though it is highly effective against many Gram-negative bacteria, its general clinical use is limited due to its adverse side effects on kidney and nerve cells. However, this antibiotic is increasingly used as a last-line drug for the treatment of multi-drug resistant Gramnegative isolates [1]. Colistin causes bacterial cell lysis due to its binding with anionic molecules, i.e, lipopolysaccharide located on the outer membrane of Gram-negative bacteria [2]. Colistin is one of the antibiotics showing effectiveness for treating multidrugresistant Enterobacteriaceae, producing carbapenemases like Metallo $\beta$-lactamase (New Delhi Metallo- $\beta$ lactamase) and serine carbapenemases (Klebsiella pneumoniae carbapenemase) as well [3]. The rise of resistance against carbapenem in the last decade has resulted in the extensive use of colistin combination therapy as a significant treatment option. However, the rise of resistance against colistin among Gram-negative pathogens may lead to infections that are extremely difficult to treat using antibiotics [4].

In Nepal, the clinical, food, and food animal isolates are increasingly becoming colistin-resistant due to clinicians' imprudent use of the antibiotic and uncontrolled use of colistin in animal farms as food preservatives and as an animal growth promoter. This threat is surging day by day while the investigation of such pathogens is very insufficient. To fill this gap, we conducted this review to know the prevalence and other characteristics of colistinresistant bacterial isolates in Nepal.

\section{Materials and methods}

\section{Literature search}

A systematic literature search was carried out for colistinresistant Gram-negative bacterial isolates in Nepal using various electronic databases (Pubmed and NepJol). In addition to published articles, unpublished materials were also analyzed. The following keywords were used in the literature search for published articles: colistin resistance, Gram-negative isolates, Nepal, multi-drug resistant bacterial isolates, extremely drug resistance, and polymyxin resistance.

\section{Inclusion criteria}

Articles which included the following information in abstract and text were selected;

i) reported colistin-resistant Gram-negative isolates from Nepal,

ii) included various features of colistin-resistant isolates like bacterial isolate, prevalence, study period, source specimen, study site, antibiotic susceptibility profile, and presence of other resistance genes.

\section{Exclusion criteria}

The following were the exclusion criteria.

i) articles lacking all or most of the variables mentioned above,

ii) abstract only articles,

iii) articles not in English, and

iv) meta-analysis.

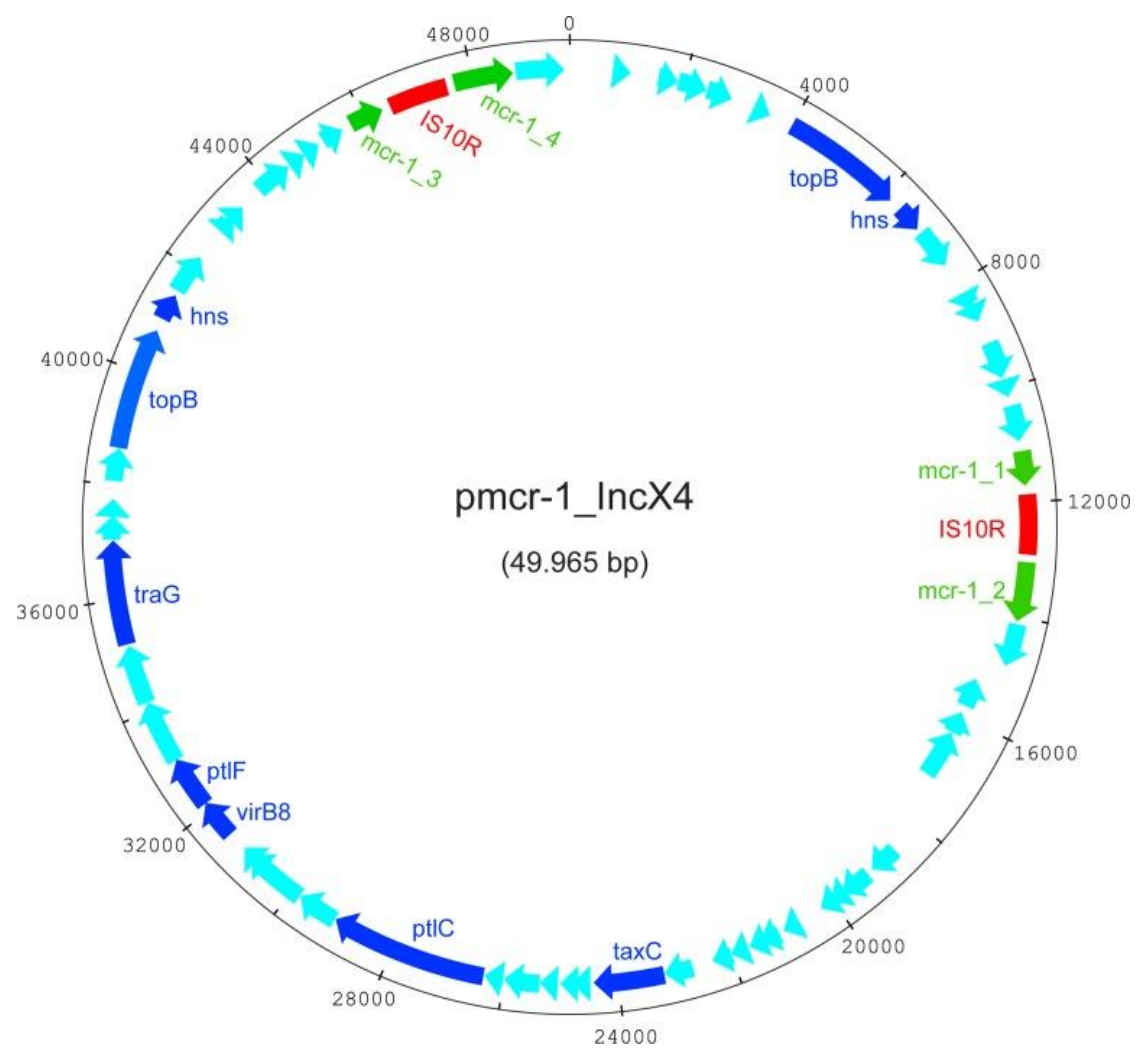

Figure 1: Circular representation of the IncX4 plasmid containing the mcr-1 gene from colistin sensitive E. coli.

$m c r-1 \quad$ sequence is represented in green colour. IS10R insertion sequence, which is interrupting the mcr-1 gene is in red colour. Arrows show open reading frames (ORFs). Nucleotide positions are in numbers. Figure adopted from Terveer et al [1] 


\begin{tabular}{|c|c|c|c|c|c|c|c|}
\hline Isolates & $\begin{array}{l}\text { Study } \\
\text { period }\end{array}$ & $\begin{array}{l}\text { Prevalence } \\
\quad(\%)\end{array}$ & $\begin{array}{c}\text { Source } \\
\text { specimen }\end{array}$ & $\begin{array}{l}\text { Detection } \\
\text { method }\end{array}$ & $\begin{array}{l}\text { Study } \\
\text { site }\end{array}$ & $\begin{array}{l}\text { Resistance } \\
\text { genes }\end{array}$ & Resistance against \\
\hline $\begin{array}{l}\text { Acinetobacter } \\
\text { [5] }\end{array}$ & 2014 & 1.3 & - & $\begin{array}{l}\text { Disc } \\
\text { diffusion }\end{array}$ & NINAS & - & - \\
\hline $\begin{array}{l}\text { Providencia } \\
\text { rettegeri }[6]\end{array}$ & 2012 & - & $\begin{array}{l}\text { Pus } \\
\text { sputum }\end{array}$ & MIC & TUTH & $\begin{array}{l}\text { NDM-1, OXA- } \\
10 \\
\text { VEB-1, TEM-1, } \\
\text { ADC-67, } \\
\text { armA, aadA1, } \\
\text { aadA2 }\end{array}$ & $\begin{array}{l}\text { piperaillin, ceftazidime, cefepime, } \\
\text { aztreonam, arbekacin, amikacin, gentamicin, } \\
\text { ciprofolxacin }\end{array}$ \\
\hline $\begin{array}{l}\text { Acinetobacter } \\
\text { [7] }\end{array}$ & 2015 & 2 & - & $\begin{array}{l}\text { Disc } \\
\text { diffusion }\end{array}$ & NMC & - & - \\
\hline $\begin{array}{l}\text { K. pneumoniae } \\
{[8]}\end{array}$ & 2011 & - & Blood & $\begin{array}{l}\text { disc } \\
\text { diffusion }\end{array}$ & PAHS & - & $\begin{array}{l}\text { ampicillin, amikacin, cefepime, cefoxitin, } \\
\text { cefotaxime, ceftriaxone, chloramphenicol, } \\
\text { cefuroxime, ertapenem, ciprofloxacin, } \\
\text { gentamicin, nalidixic acid, nitrofurantoin, } \\
\text { ofloxacin, piperacillin-tazobactam, } \\
\text { tobramycin }\end{array}$ \\
\hline $\begin{array}{l}\text { E. coli } \\
\text { Klebsiella } \\
\text { Pseudomonas } \\
\text { Acinetobacter } \\
\text { Enterobacter } \\
\text { Citrobacter [9] }\end{array}$ & $\begin{array}{l}2016- \\
17\end{array}$ & 2.8 & $\begin{array}{l}\text { Urine } \\
\text { Blood } \\
\text { Pus } \\
\text { Sputum } \\
\text { Body fluids }\end{array}$ & MIC & ANHAS & mcr-1 & $\begin{array}{l}\text { ceftazidime, ceftriaxone, ciprofloxacin, } \\
\text { gentamicin }\end{array}$ \\
\hline E. coli $[10]$ & $\begin{array}{l}2015- \\
16\end{array}$ & 5.24 & - & $\begin{array}{l}\text { Disc } \\
\text { diffusion }\end{array}$ & MTH & - & $\begin{array}{l}\text { gentamicin, piperaciiln-tazobactam, } \\
\text { amikacin, } \\
\text { ciprofloxacin, aztreonam }\end{array}$ \\
\hline $\begin{array}{l}\text { Acinetobacter } \\
{[11]}\end{array}$ & 2018 & 5.1 & - & $\begin{array}{l}\text { Disc } \\
\text { diffusion }\end{array}$ & MTH & & - \\
\hline
\end{tabular}

\begin{tabular}{|c|c|c|c|c|c|c|c|}
\hline Isolates & $\begin{array}{l}\text { Study } \\
\text { period }\end{array}$ & $\begin{array}{l}\text { Prevalen } \\
\text { ce }(\%)\end{array}$ & $\begin{array}{l}\text { Source } \\
\text { specimen }\end{array}$ & $\begin{array}{l}\text { Detection } \\
\text { method }\end{array}$ & $\begin{array}{l}\text { Study } \\
\text { site }\end{array}$ & $\begin{array}{l}\text { Resistance } \\
\text { genes }\end{array}$ & Resistance against \\
\hline E. coli $[12]$ & - & 22.8 & $\begin{array}{l}\text { chicken } \\
\text { cloacal } \\
\text { swabs }\end{array}$ & MIC & KTM & $\begin{array}{l}\text { mcr-1, } \\
\text { tet, sul, qnr, } \\
\text { dfr, and } \\
\text { blaCTX-M }\end{array}$ & $\begin{array}{l}\text { ciprofloxacin, tetracycline, and } \\
\text { sulfamethoxazole-trimethoprim }\end{array}$ \\
\hline $\begin{array}{l}\text { Salmonella } \\
{[13]}\end{array}$ & 2015 & 10.7 & $\begin{array}{l}\text { poultry } \\
\text { liver, } \\
\text { muscles } \\
\text { and, } \\
\text { gizzard }\end{array}$ & - & $\mathrm{CHT}$ & - & Furazolidone \\
\hline E. coli $[13]$ & 2012 & 25.9 & $\begin{array}{l}\text { minced } \\
\text { buffalo } \\
\text { meat }\end{array}$ & - & CHT & - & Cotrimoxazole, enrofloxacin \\
\hline $\begin{array}{l}\text { E. coli } \\
{[13]}\end{array}$ & 2012-13 & 69 & Milk & & KTM & - & $\begin{array}{l}\text { doxycycline, cotrimoxazole, } \\
\text { neomycin, azithromycin }\end{array}$ \\
\hline
\end{tabular}

KTM - Kathmandu, CHT - Chitwan

\section{Data extraction}

The following variables were extracted from the selected studies. Bacterial species that are resistant to colistin, the incidence of resistance, research period, site of study, drug resistance pattern, co-existence of other antibiotic resistance genes, type of sample, and method of detection of colistin resistance. 


\section{Results}

Colistin resistance among clinical isolates was first reported in 2012 among Providencia rettgeri at Tribhuvan University Teaching Hospital. Then on various Gramnegative isolates have been detected with no sensitivity against it. The prevalence range of colistin resistance among the clinical Gram-negative isolate was $1.3-5.24 \%$ (Table 1). This resistance mechanism is common among Acinetobacter, E. coli, Klebsiella, and Providencia, respectively. Many of these isolates also co-produced other resistance genes like carbapenemases, betalactamases, Aminoglycoside adenyl transferase, aminoglycoside resistance methylase, etc.

Colistin resistance was more prevalent in animal isolates in comparison to clinical isolates. Colistin resistance is common among animal $E$. coli isolates. The prevalence of colistin resistance was $22.8-69 \%$ in E. coli and $10.7 \%$ in Salmonella spp, respectively (Table 2). E. coli isolates obtained from chicken cloacal swabs co-produced many resistance genes. Though there is no information about the susceptibility pattern of all of these isolates, studies that included this information reported high drug resistance of these isolates (Table 2).

\section{Discussion}

Colistin resistance in clinical, food, and food animal isolates is a tremendous public health problem worldwide. This resistance mechanism is increasing gradually both in clinical and animal isolates. The major cause of this resistance is the use of colistin in animal farms as an animal food preservatives and growth promoters. Rise of colistin resistance among animal isolates is a severe threat to public health as these isolates can easily infect the peoples working on animal farms and related industries. Such isolates may also spread to water sources as well as act as a reservoir on the environment. Resistance to this last line drug causes enormous treatment difficulties in patients suffering from MDR and XDR isolates as colistin is the drug of choice for their treatment.

The prevalence of colistin resistance among clinical Gram-negative isolates was below 6\%. This finding is comparable with the findings of Dalmolin et al. as the average prevalence of colistin resistance was around 7\% among E. coli, Klebsiella pneumoniae, and Enterobacter spp [14]. While the prevalence was significantly different in comparison to this study as the prevalence was around $10 \%$ among E. coli, Klebsiella, and Pseudomonas in India [15]. Likewise, the rate of resistance was only 0.67 $\%$ among Enterobacteriaceae in Spain [16]. These alterations in prevalence may be due to the difference in the study period, differences in the detection method, the difference in colistin prescription pattern, etc. In Nepal, colistin resistance was higher in Acinetobacter, E. coli, and Klebsiella spp, followed by Providencia, Pseudomonas, Enterobacter, and Citrobacter spp. This result indicates that many significant Gram-negative isolates pose mechanism for colistin resistance. Various other authors have also reported colistin resistance among a variety of Gram-negative isolates including Acinetobacter and Pseudomonas [17], E. coli, K. oxytoca, K. pneumoniae, Acinetobacter iwoffii, E. agglomerans, Enterobacter cloacae, P. putida, and Pseudomonas aeruginosa [18], Klebsiella, E. coli, Enterobacter, and Acinetobacter [19], and Klebsiella [20].

Many colistin-resistant clinical isolates were resistant to a wide variety of antimicrobial agents, including penicillins, cephalosporins, monobactams, carbapenems, aminoglycosides, quinolones, nitrofurans, etc.

The resistance of these isolates against a wide variety of conventional drugs is reported worldwide. Colistin resistant $K$. pneumoniae from Pakistan was resistant to twenty-three antimicrobial agents from ten antimicrobial groups while it was sensitive only to tigecycline [21]. Similarly, colistin-resistant Acinetobacter isolates were not susceptible to imipenem, meropenem, ampicillinsulbactam, ciprofloxacin, gentamicin, and amikacin [22]. Very similar antibiotic resistance pattern is reported by other authors as well [23, 24, 25]. Some of these isolates were also positive for many other resistant determinants, including Metallo-beta-lactamase, oxacillinase, betalactamase, etc. conferring resistance to a wide array of antibiotics. Production of other resistance genes by these isolates is quite common as there are reports coproduction of $m c r-1$, NDM-1, CTX-M-14, CTX-M-15, CTX-M-55, and TEM-1 by colistin-resistant E. coli isolates from china [25], gyrA, aadA1, TEM, strA, ampC, mcr-1, etc. by highly virulent E. coli isolates from Qatar [24]. Likewise, colistin nonsusceptible Klebsiella pneumoniae isolates were positive for SHV, TEM, CTXM-1, OXA-1, CMY-16 genes [26].

Incidence of colistin resistance was comparatively higher among animal isolates concerning clinical isolates as up to $69 \%$ E. coli isolates recovered from milk were resistant against colistin. Various studies have reported a high proportion of colistin resistance among various bacterial isolates obtained from animal sources. The study of Liu et al. [27] reported that $76.9 \%$ of pig E. coli isolates were resistant against colistin. In China, the colistin resistance rate was $54.25 \%, 35.96 \%$, and $26.92 \%$ among E. coli isolates from pig, chicken, and cattle fecal swabs, respectively [28]. Excluding the huge colistin resistance in milk $E$. coli isolates, the prevalence range among $E$. coli and Salmonella was within $10-27 \%$. Very matching colistin resistance rate is indicated by the study of Huang et al. as the incidence was $24.1 \%$ on pig farms, $24.3 \%$ at pig slaughterhouses, and $14 \%$ and $9.5 \%$ at chicken farms and slaughterhouse respectively [29]. E. coli was the major isolate among various colistin-resistant bacterial isolates obtained from various animal samples. The predominance of $E$. coli isolates resistant to colistin is also reported earlier [30, 31]. In Nepal, Salmonella was also 
JBS 2020;7(1):33-39

resistant to colistin in addition to E. coli. This resistance mechanism has been reported in Salmonella [32], Klebsiella pneumoniae in Iran [33], Shigella flexneri in China [34].

Meat samples, milk, and cloacal swabs of food animals were the source of these isolates in Nepal. Such isolates have been detected from various birds, pigs, chicken meat, pork, and vegetables [31]. These isolates are limited not only in Gram-negative pathogens, but they have also been reported among Staphylococcus and Bacillus spp from mastitis positive cattle in Nepal [35]. This widespread dissemination of colistin resistance among a wide variety of bacteria and their high incidence is a significant global challenge. Not only this, but there are also reports zoonotic transmission of colistin resistance to humans [3638]. Hence, a detailed understanding of these pathogens is necessary to prevent their transmission from animals to humans and prevent their uncontrolled spread among clinical, food, and animal isolates in Nepal.

\section{Conclusion}

Colistin resistance has been detected among clinical, animal, and food isolates in Nepal for a few years among Gram-negative isolates. High resistance observed mainly in animal, and food isolates. Resistance to almost all of the commonly used antibiotics is frequent among these isolates in addition to the co-production of various drug resistance genes. It is a great public health concern in Nepal and requires more insight to ascertain the sources of contamination. Antimicrobial resistance modules and rational use of antibiotics in hospitals and at the community level should be included as a part of the education program. Curricula and recommendations for treatment need to be evaluated and reviewed periodically. Public-private partnership approaches should be closely monitored for the rational use of antibiotics based on public interest to promote antimicrobial stewardship. It is also necessary to establish a monitoring program and to develop awareness among health professionals. We should be very aware of the use of antibiotics, of health and hygiene practices, of good hygiene, and of limiting the use of antibiotics in animals and farms.

\section{Abbreviations}

Extensively drug-resistant (XDR), Minimum Inhibitory Concentration (MIC), Multidrug-resistant (MDR), New Delhi Metallo- $\beta$-lactamase (NDM)

\section{Acknowledgments}

None.
Authors' contribution
a. Study planning: SPD, AP
b. Manuscript writing: SPD, AP
c. Manuscript revision: SPD, AP

d. Final approval: SPD, AP

e. Agreement to be accountable for all aspects of the work: SPD, AP

\section{Funding}

There was no funding for this work.

\section{Availability of data and materials}

All data and materials available as part of the article, and no additional source data are required.

\section{Competing interests}

None, declared.

\section{Publisher's Note}

NHRS remains neutral with regard to jurisdictional claims in published maps and institutional affiliations.

The publisher shall not be legally responsible for any types of loss, actions, claims, proceedings, demand or costs or damages whatsoever or howsoever caused arising directly or indirectly in connection with or arising out of the use of this material.

\section{Author information}

${ }^{1}$ Surya Prasad Devkota, Lecturer, Department of Microbiology, Pokhara Bigyan Tatha Prabidhi campus, Nayabazzar, Pokhara, Nepal

${ }^{1}$ Lecturer, School of Health and Allied Sciences, Pokhara University ORCID

${ }^{2}$ Ashmita Paudel, Lecturer, Department of Microbiology, Regional College of Health Science and Technology, Nayabazzar, Pokhara, Nepal $\underline{\text { ORCID }}$

\section{References}

1. Terveer EM, Nijhuis RHT, Crobach MJT, Knetsch CW, Veldkamp KE, Gooskens J et al. Prevalence of colistin resistance gene (mcr-1) containing Enterobacteriaceae in feces of patients attending a tertiary care hospital and detection of a mcr-1 containing, colistin susceptible E. coli. PLoS ONE. 2017; 12: e0178598.

https://doi.org/10.1371/journal.pone.0178598

2. MacNair CR, Stokes JM, Carfrae LA, FiebigComyn AA, Coombes BK and Mulvey MR. et al. Overcoming mcr-1 mediated colistin resistance with colistin in combination with other antibiotics. Nature Communication. 2018; 9: Article no. 458. https://doi.org/10.1038/s41467-018-02875-z

3. Walkty A, Karlowsky JA, Adam HA, Lagacé-Wiens P, Baxter M, Mulvey MR et al. Frequency of MCR1-mediated colistin resistance among Escherichia coli clinical isolates obtained from patients in Canadian hospitals (CANWARD 2008-2015). CMAJ Open. 2016; 4: E641-E645. 
https://doi.org/10.9778/cmajo.20160080

4. Arjun R, Gopalakrishnan R, Nambi PS, Kumar DS, Madhumitha R, and Ramasubramanian V. A Study of 24 Patients with Colistin-Resistant Gram-negative Isolates in a Tertiary Care Hospital in South India. Indian J Crit Care Med. 2017; 21: 317-321. https://doi.org/10.4103/ijccm.IJCCM_454_16

5. Thapa E, Thapa R, Singh A, Pokharel BM, Devkota U. Antibiotic Resistance Pattern Of Bacterial Isolates From Post- Tracheostomised Patients Attending Tertiary Care Hospital In Nepal. Journal of Institute of Science and Technology. 2016; 21 (1):129-32. https://doi.org/10.3126/jist.v21i1.16064

6. Tada T, Miyoshi-Akiyama T, Dahal RK, Sah MK, Ohara $\mathrm{H}$ et al. NDM-1 Metallo- $\beta$-Lactamase and ArmA 16S rRNA methylase producing Providencia rettgeri clinical isolates in Nepal. BMC Infect Dis. 2014; 14:56.

https://doi.org/10.1186/1471-2334-14-56

7. Amatya R, Acharya D. Prevalence of tigecycline resistant multidrug resistant Acinetobacter calcoaceticus-Acinetobacter baumannii complex from a tertiary care hospital in Nepal. Nepal Med Coll J. 2015; 17(1-2):83-6.

8. Amatya P, Joshi S, Shrestha S. Outbreak of Extended Spectrum Beta Lactamase Producing Klebsiella Species Causing Neonatal Sepsis at Patan Hospital in Nepal. Journal of Patan Academy of Health Sciences. 2014;1(1):20-5. https://doi.org/10.3126/jpahs.v1i1.13011

9. Paudel A. Detection of Plasmid Mediated Colistin Resistance Gene mcr-1 In Clinical Gram-Negative Isolates at Tertiary Care Hospital [Dissertation]. Saint Xavier's College (Tribhuvan University), Maitighar, Kathmandu, 2017.

10. Devkota SP, Sharma S, Bhatta DR, Paudel A, Sah AK and Kandel BP. Prevalence of the bla NDM gene among Metallo- $\beta$-lactamase-producing Gramnegative isolates from western. Nepal. Journal of Global Antimicrobial Resistance. 2018; 12: 3-4. https://doi.org/10.1016/j.jgar.2017.11.003

11. Bhatta DR, Hamal D, Shrestha R, Supram HS , Joshi $\mathrm{P}$ et al. Burden of multidrug resistant respiratory pathogens in intensive care units of tertiary care hospital. Asian Journal of Medical Sciences. 2019; 10 (2):14-9.

https://doi.org/10.3126/ajms.v10i2.21098

12. Joshi PR, Thummeepak R, Paudel S, Acharya M, Pradhan $\mathrm{S}$ et al. Molecular Characterization of Colistin-Resistant Escherichia coli Isolated from Chickens: First Report from Nepal. Microb Drug Resist. 2019; 25(6): 846-54. https://doi.org/10.1089/mdr.2018.0326

13. Acharya KP, Wilson RT. Antimicrobial Resistance in Nepal. Front. Med. 2019; 6:105. https://doi.org/10.3389/fmed.2019.00105

14. Dalmolin TV, De Lima-Morales D, Barth AL. Plasmid mediated colistin resistance: what do we know?. J Infectiology. 2018; 1(2):16-22. https://doi.org/10.29245/2689-9981/2018/2.1109

15. Jain S. Emergence of Colistin Resistance among Gram Negative Bacteria in Urinary Tract Infections from Super Specialty Hospital of North India. International Journal of Infectious Diseases. 2018; 73S:133. https://doi.org/10.1016/j.ijid.2018.04.3716

16. Prim N, Turbau M, Rivera A, Rodríguez-Navarro J, Coll P, Mirelis B. Prevalence of colistin resistance in clinical isolates of Enterobacteriaceae: A four-year cross-sectional study. J Infect. 2017; 75(6): 493-8. https://doi.org/10.1016/j.jinf.2017.09.008

17. Maraki S, Mavros MN, Kofteridis DP, Samonis G, Falagas ME. Epidemiology and antimicrobial sensitivities of 536 multi-drug-resistant gramnegative bacilli isolated from patients treated on surgical wards. Surg Infect (Larchmt). 2012; 13(5):326-31.

https://doi.org/10.1089/sur.2011.115

18. Caselli E, D'Accolti M, Soffritti I, Piffanelli M, Mazzacane S. Spread of mcr-1-Driven Colistin Resistance on Hospital Surfaces, Italy. Emerg Infect Dis. 2018; 24(9): 1752-3. https://doi.org/10.3201/eid2409.171386

19. El Sayed Zaki M, ElKheir NA and Mofreh M. Molecular study of colistin resistant clinical isolates of Enterobacteriaceae species. J Clin Mol Med. 2018; 1(1):1-4. https://doi.org/10.15761/JCMM.1000103

20. Rolain JM, Kempf M, Leangapichart T, Chabou S, Olaitan AO, Le Page S et al. Plasmid-Mediated mcr1 Gene in Colistin-Resistant Clinical Isolates of Klebsiella pneumoniae in France and Laos. Antimicrob Agents Chemother. 2016; 60(11):69946995. https://doi.org/10.1128/AAC.00960-16

21. Lomonaco S, Crawford MA, Lascols C, Timme RE, Anderson K, Hodge DR et al. Resistome of carbapenem- and colistin-resistant Klebsiella pneumoniae clinical isolates. PLoS One. 2018; 13(6): e0198526. https://doi.org/10.1371/journal.pone.0198526

22. Cafiso V, Stracquadanio S, Lo Verde F, Gabriele G, Mezzatesta ML, Caio C et al. Colistin Resistant A. baumannii: Genomic and Transcriptomic Traits Acquired Under Colistin Therapy. Front Microbiol. 2019; 9:3195. https://doi.org/10.3389/fmicb.2018.03195

23. Abdulzahra AT, Khalil MAF, Elkhatib WF. First report of colistin resistance among carbapenemresistant Acinetobacter baumanniiisolates recovered from hospitalized patients in Egypt. New Microbes 
New Infect. 2018; 26:53-8.

https://doi.org/10.1016/j.nmni.2018.08.007

24. Forde BM, Zowawi HM, Harris PNA, Roberts L, Ibrahim E, Shaikh N et al. Discovery of mcr-1Mediated Colistin Resistance in a Highly Virulent Escherichia coli Lineage. mSphere. 2018; 3(5): pii: e00486-18. https://doi.org/10.1128/mSphere.00486-18

25. Zheng B, Dong H, Xu H, Lv J, Zhang J, Jiang X et al. Coexistence of MCR-1 and NDM-1 in Clinical Escherichia coli Isolates. Clin Infect Dis. 2016; 63(10):1393-5. https://doi.org/10.1093/cid/ciw553

26. Tanfous FB, Raddaoui A, Chebbi Y, Achour W. Epidemiology and molecular characterization of colistin-resistant Klebsiella pneumoniae isolates from immunocompromised patients in Tunisia. Int $\mathbf{J}$ Antimicrob Agents. 2018; 52(6):861-5 https://doi.org/10.1016/j.ijantimicag.2018.08.022

27. Liu Y, Liu JH. Monitoring Colistin Resistance in Food Animals, An Urgent Threat. Expert Rev Anti Infect Ther. 2018; 16(6): 443-6. https://doi.org/10.1080/14787210.2018.1481749

28. Zhang X, Zhang B, Guo Y, Wang J, Zhao P, Liu J et al. Colistin resistance prevalence in Escherichia coli from domestic animals in intensive breeding farms of Jiangsu Province. Int J Food Microbiol. 2019; 291:87-90.

https://doi.org/10.1016/j.ijfoodmicro.2018.11.013

29. Huang X, Yu L, Chen X, Zhi C, Yao X, Liu Yet al. High Prevalence of Colistin Resistance and mcr-1 Gene in Escherichia coli Isolated from Food Animals in China. Front Microbiol. 2017; 8:562. https://doi.org/10.3389/fmicb.2017.00562

30. Alba P, Leekitcharoenphon P, Franco A, Feltrin F, Ianzano A, Caprioli, A et al. Molecular epidemiology of mcr-encoded colistin resistance in Enterobacteriaceae from food-producing animals in Italy revealed through the EU harmonised antimicrobial resistance monitoring. Front Microbiol. 2018; 9: 1217. https://doi.org/10.3389/fmicb.2018.01217

31. Skov RL, Monnet DL. Plasmid-mediated colistin resistance (mcr-1 gene): three months later, the story unfolds. Euro Surveill. 2016; 21(9): 30155.

https://doi.org/10.2807/15607917.ES.2016.21.9.30155

32. Lima T, Domingues S, Da Silva GJ. PlasmidMediated Colistin Resistance in Salmonella enterica: A Review. Microorganisms. 2019; 7(2): pii: E55. https://doi.org/10.3390/microorganisms7020055

33. Pishnian Z, Haeili M, Feizi A. Prevalence and molecular determinants of colistin resistance among commensal Enterobacteriaceae isolated from poultry in northwest of Iran. Gut Pathogens. 2019; 11: Article number: 2. https://doi.org/10.1186/s13099-019-0282-0

34. Liang B, Roberts AP, Xu X, Yang C, Yang X, Wang $\mathrm{J}$ et al. Transferable Plasmid-Borne mcr-1 in a Colistin-Resistant Shigella flexneri Isolate. Appl Environ Microbiol. 2018; 84(8): pii: e02655-17. https://doi.org/10.1128/AEM.02655-17

35. Central Veterinary Laboratory, Kathmandu, Nepal. Annual Technical Report (2014/15). Available from http://www.cvl.gov.np/uploads/files/5324820354.pd $\underline{\mathrm{f}}$, accessed on 20 June 2020

36. Trung NV, Matamoros S, Carrique-Mas JJ, Nghia NH, Nhung NT, Chieu TTB et al. Zoonotic Transmission of mcr-1 Colistin Resistance Gene from Small-Scale Poultry Farms, Vietnam. Emerg Infect Dis. 2017; 23(3):529-32. https://doi.org/10.3201/eid2303.161553

37. Olaitan AO, Chabou S, Okdah L, Morand S, Rolain JM. Dissemination of the mcr-1 colistin resistance gene. Lancet Infect Dis. 2016; 16:147. https://doi.org/10.1016/S1473-3099(15)00540-X

38. Zhang XF, Doi Y, Huang X, Li HY, Zhong LL, Zeng KJ et al. Possible transmission of mcr-1harboring Escherichia coli between companion animals and human. Emerg Infect Dis. 2016;22: 1679-81. https://doi.org/10.3201/eid2209.160464 